\title{
Burr Cell Count
}

National Cancer Institute

\section{Source}

National Cancer Institute. Burr Cell Count. NCI Thesaurus. Code C74701.

The determination of the number of Burr cells present in a sample. 